\title{
'What Do We Do with the Art of Monstrous Men?' Betrayal and the Feminist Ethics of Aesthetic Involvement
}

\author{
Sarah Stewart-Kroeker
}

The \#MeToo movement has put a spotlight on sexual harassment and abuse in a number of industries, notably the arts. It has raised a set of questions about how to receive the artistic works of the accused, particularly when such work has been beloved or formative for an individual, and collectively when it has cultural significance and influence. Claire Dederer, writing in The Paris Review, posed the question bluntly in her piece, "What Do We Do with the Art of Monstrous Men?" This question, and the range of (often perplexed) responses to it, reveal the lack of adequate resources to evaluate responses to an artist's actions that may bear on our aesthetic valuations of the artist's work and that may be experienced as quite intimately personal. What do we do with the sense of betrayal that may follow on the discovery of an artist's bad behavior? What are the implications of consuming of such art? What concepts and norms might help to guide reflection? These questions bear on the ethical significance of love and appreciation for artworks and artists, and, more broadly, the ethical consumption of artworks. This paper responds to these questions in two ways: first, it develops an account of "aesthetic involvement" to elaborate the sense of betrayal that may follow accusations or revelations of sexual harassment and abuse. Second, it proposes a feminist ethics of aesthetic involvement in response to such betrayals and to dilemmas about the individual and collective ethical consumption of artworks.

In fall 2017, a wave of accusations against "Shitty Media Men" - the title of an anonymous, crowdsourced spreadsheet naming sexual abusers and harassers in the industry ${ }^{1}$ - spurred a series of high-profile revelations, firings, and criminal charges, as well as a massive social media campaign, \#MeToo, taking up the affirmation at the heart of a movement begun by Tarana Burke more than a decade prior to help young women of color who had suffered sexual abuse. The spotlight on problems of sexual harassment and abuse has since

${ }_{1}^{1}$ Moira Donegan, "I Started the Media Men List. My name is Moira Donegan." The Cut, January 10, 2018. Online at https://www.thecut.com/2018/01/moira-donegan-i-started-the-media-menlist.html (accessed 2018-11-8). 
broadened to other industries, including academia. ${ }^{2}$ The moment has been called "a reckoning."

In the arts, this reckoning poses a particular set of questions about how to receive the artistic work of the accused, particularly when such work has been beloved or formative for an individual, and collectively when it has cultural significance and influence. Indeed, the question of engaging the creative output of artists whose ethical actions we find lacking may be the "central pop-cultural question" of the current moment. ${ }^{3}$ The debate is being waged in newspaper columns, essays, innumerable think-pieces and hot takes, casual and not-so-casual conversation (for this reason, I draw significantly on popular materials in the following discussion). Claire Dederer, writing in The Paris Review, posed the question bluntly in the title of her piece, "What Do We Do with the Art of Monstrous Men?"4 But this raises a set of subsequent questions over which she puzzles more than a little ambivalently: Ought we try to separate the art from the artist, the maker from the made? ... Or do we believe genius gets special dispensation, a behavioral hall pass? And how does our answer change from situation to situation? ... Do we withhold our support if the person is alive and therefore might benefit financially from our consumption of their work? Do we vote with our wallets? If so, is it okay to stream, say, a Roman Polanski movie for free? Can we, um, watch it at a friend's house? 5

Dederer's question (echoed by others ${ }^{6}$ ), and ambivalent response, reveal the lack of adequate resources to evaluate betrayals that respond to an artist's actions and that may

2 In the field of Christian ethics, for example, there is a years-long debate about how to receive the legacy of John Howard Yoder. See Rachel Waltner Goossen, “Defanging the Beast: Mennonite Responses to John Howard Yoder's Sexual Abuse," Mennonite Quarterly Review 89 (January 2015), pp. 7-80; David Cramer, Jenny Howell, Jonathan Tran, Paul Martens, "Scandalizing John Howard Yoder," The Other Journal: An Intersection of Theology \& Culture, July 7, 2014. Online at https:/ / theotherjournal.com/2014/07/07/scandalizing-john-howard-yoder/ (accessed 2018-11-8); Stanley Hauerwas, “In Defence of 'Our Respectable Culture': Trying to Make Sense of John Howard Yoder's Sexual Abuse," ABC Religion and Ethics, October 18, 2017. Online at http:/ / www.abc.net.au/religion/articles/2017/10/18/4751367.htm (accessed 2018-11-8); Hilary Scarsella, "Not Making Sense: Why Stanley Hauerwas's Response to Yoder's Sexual Abuse Misses the Mark," ABC Religion and Ethics, Updated 1 Dec 2017 (First posted 2017-11-30). Online at http:/ / www.abc.net.au/religion/articles/2017/11/30/4774014.htm (accessed 2018-11-8). In philosophy, the debate about the reception of Heidegger in light of his anti-Semitism has taken on new intensity with the recent publication of the Black Notebooks. See for example Ingo Farin and Jeff Malpas (eds), Reading Heidegger's Black Notebooks 1931-1941 (Cambridge: MIT Press, 2016); Andrew Mitchell and Peter Trawny (eds), Heidegger's Black Notebooks: Responses to Anti-Semitism (Columbia University Press, 2017).

3 Daniel Kolitz, “Academics Explain David Foster Wallace To Me," The Outline, July 25, 2018, https:/ / theoutline.com/post/5543/david-foster-wallace-conference-profile?zd=1\&zi=hoxjdain (accessed 2018-11-6).

4 Claire Dederer, "What Do We Do With the Art of Monstrous Men?," The Paris Review, November 20, 2017. Online at https:/ / www.theparisreview.org/blog/2017/11/20/art-monstrous-men/ (accessed_2018-11-8).

5 Dederer, "Monstrous Men."

${ }^{6}$ Sarah Lyall and David Itzkoff, "Charlie Rose, Louis C.K., Kevin Spacey: Rebuked. Now What Do We Do With Their Work?" The New York Times, November 24, 2017. Online at https:/ / www.nytimes.com/2017/11/24/arts/charlie-rose-kevin-spacey-louis-ck-art.html (accessed 2018-11-8); Amanda Hess, "How the Myth of the Artistic Genius Excuses the Abuse of Women," The New York Times, November 10, 2017. Online at 
bear on our aesthetic valuations of the artist's work and that may be experienced as quite intimately personal. What do we do with the sense of betrayal that may follow on the discovery of an artist's bad behavior? What are the implications of consuming of such art? What concepts and norms might help to guide reflection? As Kolitz puts it, what do you say (and do) "when you're told, over and over, that the work you love is tainted, and that loving it taints you too?"7 Underlying these are deep and ambiguous questions about how to construe the relationship between art and life - both the artist's and the viewer-lover's - and the ethics of consuming art in light of those relationships. In other words, there are questions about both the ethical significance of the love for and involvement with artworks and artists, and, more broadly, questions about the ethical consumption of artworks. ${ }^{8}$ At stake in both sets of questions are concerns about the ways in which we are formed by the images and works we consume (a concern that is heightened with respect to works we love and hold in high regard), and also how consuming and cherishing particular works contributes to moral formation. ${ }^{9}$

Though the potential scope of this set of issues is large, I will focus on artists who have been accused of sexual harassment and abuse in light of the feminist "reckoning" in the arts spurred by the \#MeToo movement. My starting point is the articulated dilemma that these accusations create for those who have highly regarded specific artworks and consequently been formed by them and found themselves "involved" with them insofar as they have been personally significant, which is why my discussion draws significantly on two first-personal accounts by people grappling with how to relate to artworks that have been formative and beloved in their lives. Because the dilemmas arise not simply out of judgments of aesthetic value (though these are at play) but from a kind of involvement with the artwork that entails both aesthetic regard and personally formative significance, I use the term "aesthetic involvement" to denote this relationship. ${ }^{10}$ Both of the accounts of

https:/ / www.nytimes.com/2017/11/10/arts/sexual-harassment-art-hollywood.html (accessed 2018-11-8); Svetlana Mintcheva, “Caravaggio Killed a Man. Should We Therefore Censor His Art?" The Guardian, February 3, 2018. Online at

https:/ / www.theguardian.com/commentisfree/2018/feb/03/caravaggio-killed-a-man-censorart?CMP=share_btn_fb (accessed 2018-11-8); A.O. Scott, “My Woody Allen Problem,” The New York Times, January 31 2018. Online at https:/ / www.nytimes.com/2018/01/31/movies/woodyallen.html (accessed 2018-11-8).

7 Kolitz, "Academics Explain."

8 Note that some of these questions about consumption or economic and cultural support may apply to other "arts" (scholarship, for example) as well as to other kinds of figures (public intellectuals, politicians, religious leaders, and so forth). I restrict my focus here, however, to the discussion of artists and artworks.

9 By moral formation, I mean ways in which we are shaped as moral agents: affectively, dispositionally, and intellectually, according to particular values, ideals, and principles, both consciously and unconsciously. An underlying premise of this paper, which I will not defend here, is that this formation operates aesthetically insofar as what we find appealing, attractive, and compelling - as well as what we find repulsive or disruptive - accompanies and influences our valuations of people, things, and actions (and vice versa). This is not to say that aesthetic valuations always track moral ones, or vice versa - but that in the broad and pervasive shaping of an agent, moral and aesthetic formation intersect in important ways.

10 Strong forms of aesthetic regard for works often compel attention to those works such that they generally entail significant attachments. Certainly, it is possible to make positive judgments of aesthetic value that do not entail such formative importance. And it is also possible to maintain an 
aesthetic involvement I consider in the beginning of this paper also tie their individual attachment to certain works and artists to the broader cultural importance these works and their artists enjoy.

While the following discussion touches on longstanding questions about the relationship between art and the artist's biography, the effects of art on the viewer, and the relationship between aesthetics and ethics more broadly, it does so in the context of addressing the specific set of questions around regard for and consumption of artworks that have been raised in the \#MeToo reckoning. ${ }^{11}$ I will, in what follows, account for how one can feel betrayed by an ethically "tainted" artist and their work, and offer a preliminary sketch of a feminist ethics of aesthetic involvement in response to such betrayals. ${ }^{12}$ I explore this first, with respect to individual regard for artworks that are aesthetically valued as well as beloved (individual aesthetic involvement). Second, I explore betrayals with respect to cultural aesthetic involvement: that is, artworks that enjoy a broad cultural regard for their aesthetic value and hold an important place in the "common artistic

attachment to artworks that have been personally significant in some way without considering them to be highly aesthetically valuable in their own right. Art may be formative without being highly regarded aesthetically, insofar as exposure to and consumption of art presumably has some effect on us whether or not we hold it in high regard. "Aesthetic involvement," however, designates a judgment of both aesthetic regard and personal significance, which means that the artwork's formative power at issue (and entails a particular set of dynamics with regards to betrayal).

11 Regarding the philosophical questions around ethics and aesthetics more broadly, I am particularly indebted to Berys Gaut's account of "ethicism" in Art, Emotions and Ethics (Oxford: Oxford University Press, 2007). The literature on the topic is vast; for further recent works, see R.W. Beardsmore, Art and Morality (London: Macmillan, 1971); Noël Carroll, "Art and Ethical Criticism: An Overview of Recent Directions of Research," Ethics vol. 110/2 (2000): pp. 350-387; Diané Collinson, "'Ethics and Aesthetics Are One,"” The British Journal of Aesthetics vol. 25/3 (1985): pp. 255-272; Stephen Davies (ed.), Art and its Messages: Meaning, Morality, and Society (University Park: Pennsylvania State University Press, 1997); Mary Devereaux, "Moral Judgments and Works of Art: The Case of Narrative Literature," Journal of Aesthetics and Art Criticism vol. 62 (2004): pp. 3-11; Arnold Isenberg, "Ethical and Aesthetic Criticism," in Aesthetics and the Theory of Criticism: Selected Essays of Arnold Isenberg, ed. William Callaghan et al. (Chicago: University of Chicago Press, 1973); Daniel Jacobson, “Ethical Criticism and the Vice of Moderation," in Matthew Kieran (ed.), Contemporary Debates in Aesthetics and the Philosophy of Art (Oxford: Blackwell, 2006); Matthew Kieran, "Art, Imagination, and the Cultivation of Morals," Journal of Aesthetics and Art Criticism vol. 54 (1996): pp. 337-351; Jerrold Levinson (ed.), Aesthetics and Ethics: Essays at the Intersection (Cambridge: Cambridge University Press, 1998); Hallvard Lillehammer, "Values of Art and the Ethical Question," The British Journal of Aesthetics vol. 48/4 (2008): pp. 376-394; Jennifer A. McMahon, Art and Ethics in a Material World: Kant's Pragmatist Legacy (New York: Routledge, 2014); Panos Paris, The 'Moralism' in Immoralism: A Critique of Immoralism in Aesthetics," The British Journal of Aesthetics vol. 591/2 (January 2019): pp. 13-33; Richard Posner, "Against Ethical Criticism," Philosophy and Literature vol. 21 (1997): pp. 1-27 and "Against Ethical Criticism: Part Two," Philosophy and Literature vol. 22 (1998): pp. 394-412; Robert Stecker, "The Interaction of Ethical and Aesthetic Value," British Journal of Aesthetics vol. 45 (2005): pp. 138-150.

12 In this sense, I am trying to wed Dederer's evocation of "ethical thoughts" and "moral feelings," which she distinguishes: "we tell ourselves we're having ethical thoughts when really what we're having is moral feelings." But ethics must account for moral feelings; here, I offer an ethical framework for moral feelings of betrayal by art. 
record," and thus may be said to be culturally formative, if variably formative for individuals.

\section{Art's Formative Qualities}

The relationship between a viewer, ${ }^{13}$ a work of art, and its maker creates a relational triad that may entail particular forms of intimacy. ${ }^{14}$ Certainly, a degree of separability should be maintained between these three "terms" of the triad, not least because there is a historicalcultural contingency to how this triad is construed; where the artist's personal expressiveness and authenticity is prized, this impacts the triad significantly.15 But the questions about receiving the art of the so-called "monstrous" supposes that in the contemporary context, there are ethically significant links that require attention. The questions regarding the works of "monstrous men" emerge in response to revealed biographical details that create dilemmas about both the consumption of their works as such and the aesthetic regard that we have for them: these questions range from economic support, to cultural influence, to the ethical attitudes manifest in a work, to the impact such works may have on one's own perceptions and attitudes. Elaine Scarry and Alexander Nehamas have both offered compelling descriptions of the formative relationships people may have with art (and beautiful people/things more broadly ${ }^{16}$ ). Though neither of them delves into the relationship between a viewer, a work of art, and the artist's biography directly, I suggest that if we take seriously their emphasis on art's formative and relational

${ }^{13}$ I use this term for expediency's sake since most of the works under discussion here are visual artworks, but I take the scope of this discussion to extend to non-visual arts as well.

14 Wayne Booth, for example, uses a friendship model to describe these relations. Wayne Booth, The Company We Keep: An Ethics of Fiction (Berkeley and Los Angeles: University of California Press, 1988). Gaut rightly contests this as a general model for the relationship a viewer or reader may have to the "manifest author" but also acknowledges that it may apply in certain cases. See Gaut, Art, pp. 109-114.

15 Certain questions might still apply to a medieval master painting icons of saints, for example, but surely not to the same extent as to artists whose works assert a more directly personal expressivity. On Gaut's model, expressive artistic acts impart a "manifest author" that may and may not be directly continuous with the author's real-life character. Gaut, Art, pp. 67-82. As Gaut notes, "people vary in their attitudes in different contexts and also can fashion delusive or fictional personae in their work. However, the view also allows that the artist's personality as manifested outside his work may be relevant, since it is the same person who acts in both contexts. The test must be whether, in the light of one's knowledge of the artist's attitudes outside his work, one can detect in the work traces of these attitudes." Gaut, Art, p. 74.

16 While Nehamas and Scarry are both developing accounts of beauty, neither of their accounts rest on a notion of beauty as a formal aesthetic property. Both of their accounts give a central place to affective and cognitive responses to things we find beautiful (rather than a specific aesthetic property we might call "the beautiful"), impulses toward learning that follow upon this response, and the attachments these responses generate. This makes their accounts amenable to extrapolation beyond responses to beauty alone, but to all responses to what we find aesthetically compelling such that we hold it in high regard. My interest here is not restricted to aesthetic properties or artworks with regards to beauty specifically, but to the formative and relational qualities both Nehamas and Scarry describe, which I take to be relevant for aesthetic responses broadly and not only responses to beauty as such. 
qualities, abstracting art from artist from the viewer in this relational triad is not straightforward.

According to Nehamas, we are drawn to things and people we find beautiful in some way because they beckon with a promise of happiness. ${ }^{17}$ This promise consists in the idea that by devoting a part of one's life to someone or thing we find attractive and compelling, one will come to know both the object and oneself in new and unforeseeable ways. This is transformative; it actively refashions the lover's desires and standards and understanding. ${ }^{18}$ As a result, when one enters a relationship with such people or things, one gives them power over oneself "emotionally, ethically, and intellectually, trusting [them] not to exploit it. By becoming vulnerable in this way, I put my identity at serious risk because I have no way of telling how our relationship will ultimately affect me and whether it will be for good or bad." 19 If love is propelled by this sense transformative promise, as Nehamas claims, this necessarily implies an aesthetic judgment that also shapes the self - it opens onto aesthetic involvement. Indeed, Dederer describes the impact of repeatedly viewing Roman Polanski films in direct consumptive terms: "I ate them. They became part of me, the way something loved does." 20

A.O. Scott's recent confessional, "My Woody Allen Problem," (The New York Times, 2018-1-31) illustrates this intimately formative dynamic in relation to one of the disputed figures of the \#MeToo reckoning. Woody Allen has been accused of sexually assaulting his adoptive daughter, Dylan Farrow, in what has been and continues to be a highly contentious and highly mediatized conflict. ${ }^{21}$ A number of actors and critics have weighed in on the dispute and on the attitude viewers should have towards Allen. In this first section, I focus on Dederer's and Scott's accounts of their reckoning with Allen's work, a formative figure for both of them. With regards to the accusations, Scott declares his assessment from the start: he thinks Allen is guilty. In response to an earlier scandal, Allen's affair with and subsequent marriage to Soon-Yi Previn (his long-term partner Mia Farrow's adopted daughter), Scott notes that he had then argued that Allen's personal life should be distinguished from the work. This contrasts with Dederer's account, in which she describes the Soon-Yi Previn revelation as the moment of "terrible betrayal".

17 Alexander Nehamas, Only a Promise of Happiness: The Place of Beauty in a World of Art (Princeton: Princeton University Press, 2007). Nehamas construes beauty's appeal broadly; he suggests we may be attracted (for example) to people or works that are conventionally or outwardly ugly, just as we may be repulsed by people or works that are conventionally or outwardly beautiful. In this sense, the propulsion is attraction to and love for an object, which necessarily entails finding it beautiful in some way. This emphasis on the relational qualities of attraction and love makes his account particularly relevant to aesthetic involvement broadly.

18 Nehamas, Promise, pp. 57-63.

19 Nehamas, Promise, p. 57.

20 Dederer, "Monstrous Men."

21 The search results for recent coverage in the New York Times alone yield dozens of articles. A number of these cover the flurry of accusations and responses back and forth, primarily between Ronan and Dylan Farrow on the one hand, and on the other, Moses Farrow and Soon-Yi Previn (Allen's wife and Mia Farrow's adopted daughter, who was a young girl when Allen and Farrow began their relationship). For a recap and timeline of events, see Sopan Deb and Deborah Leiderman, "Woody Allen, Mia Farrow, Soon-Yi Previn, Dylan Farrow: A Timeline," The New York Times, January 31, 2018, https:/ / www.nytimes.com/2018/01/31/movies/woody-allen-miafarrow-dylan-farrow-a-timeline.html (accessed 2018-11-2). A further number address the debate over the status of the accusations, how they should be received, and Woody Allen's artistic merits. 
The position to which Scott previously adhered, that the artist's personal life should be distinguished from the work, is the standard objection to the art/biography/viewer triad as ethically significant. ${ }^{22}$ This is more difficult to maintain with regards to an artist like Allen whose work is particularly personal: "saturated with his personality, his preoccupations, his biography and his tastes." 23 More importantly, Scott describes how powerful the image of Woody Allen as a male lead - as a sex symbol, or at least as the persistent object of women's sexual and romantic attentions - was for him as an adolescent:

\begin{abstract}
The man himself was a plausible definition of sexy. The achievement of his early movies, culminating in "Annie Hall" (his seventh feature as a director) was to turn a scrawny, bookish, self-conscious nebbish into a player. ... The aspects of his temperament held up for mockery - the hyper-intellectualism, the snobbery, the irreducible Jewishness - doubled as weapons of seduction. His self-deprecation was a tactic, a feint, a rope-a-dope, and he was plagued less by the frustration of his desires than by their fulfillment. As soon as the heart got what it wanted, it wanted something else. What impressionable, heterosexual, unathletic adolescent boy would not want a piece of that action?24
\end{abstract}

Interestingly, Dederer too describes a strong identification with Allen - "I felt like Woody Allen. ...I felt closer to him than seems reasonable for a little girl to feel about a grown-up male filmmaker." 25 This capacity to produce identification in his audience is an aspect of his particular genius, she suggests - and perhaps precisely artists with this particular talent are the ones who will elicit the strongest sense of betrayal.

In his recent re-assessment of Allen's work, Scott bluntly rejects the separation of art from artist: "the notion that art belongs to a zone of human experience somehow distinct from other human experiences is both conceptually incoherent and intellectually crippling. Art belongs to life, and anyone - critic, creator or fan - who has devoted his or her life to art knows as much." 26 Allen's persona is intimately woven into his work, which makes the aesthetic triad particularly obvious. And because of the ways in which Scott values them, the works are intimately woven into his own life. He describes watching Allen's movies - all of them, some repeatedly, from a young age:

I could, I suppose, declare that I won't watch any more of his movies. But I can hardly unwatch the ones I've seen, which is all of them, at least half more than once. And even if I could, by some feat of cinephilic sophistry, separate those movies from Mr. Allen's life, I can't possibly separate them from mine. ${ }^{27}$

Scott's attraction to a figure unconventionally attractive to women in whom he saw himself held a kind of transformative appeal ("What impressionable, heterosexual, unathletic

\footnotetext{
22 This is one feature of what Gaut terms the "autonomist" stance on the relationship between ethics and aesthetics. For the full account, see Gaut, Art, pp. 67-89.

23 Scott, "My Woody Allen Problem." Allen, who both directs and stars in many of his films, is a particularly clear case, but as Gaut shows, any continuity between the real-life author and the manifest author may be significant in this sense.

24 Scott, "My Woody Allen Problem."

25 Dederer, "Monstrous Men."

26 Scott, "My Woody Allen Problem."

27 Scott, "My Woody Allen Problem."
} 
adolescent boy would not want a piece of that action?"). Woody Allen made the nerd into a player; and not just a player, but one who liked and attracted young - sometimes very young - women, whom he would (try to) educate, and whose vulnerability and relative ignorance was often portrayed as part of their (often transient) charm. ${ }^{28}$ Scott notes that for all of Woody Allen's self-deprecation, his character exhibits:

...a powerful sense of entitlement. The Woody Allen figure in a Woody Allen movie is almost always in transit from one woman to another, impelled by a dialectic of enchantment, disappointment and reawakened desire. The rejected women appear shrewish, needy, shallow or boring. Their replacements, at least temporarily, are earnest, sensuous, generous and, more often than not, younger and less worldly than their predecessors. For a very long time, this was taken not as a self-serving fantasy but as a token of honesty, or freedom from sentimental conceptions of domestic love. ... What I find most ethically troubling about Mr. Allen's work at present is the extent to which I and so many of my colleagues have ignored or minimized its uglier aspects. A sensibility that seemed sweet, skeptical and self-scrutinizing may have been cruel, cynical and self-justifying all along. ${ }^{29}$

This epitomizes the way in which, as Berys Gaut notes, after learning about the biographical facts (or learning more about the biographical facts), one may "see attitudes in the [artworks] with greater focus and clarity than she previously had done." 30 What is particularly relevant for ethical criticism of artworks is whether an artist's "reprehensible attitudes infect their work." 31 This is a matter not just of individual concern insofar as Allen's works were personally formative for Scott, but because Allen's works are "part of the common artistic record, which is another way of saying that they inform the memories and experiences of a great many people. I don't mean this as a defense, but an acknowledgment of betrayal and shame." 32 When aesthetic involvement concerns a body of work, as it does in this case - particularly one that is not only significant to the individual but has also had an important place in what Scott calls the "common artistic record" - the relational triad between viewer, art, and artist is further heightened, as is the sense of betrayal that may then follow. ${ }^{33}$

28 Manhattan is undoubtedly the prime offender in this regard, the one eliciting the most reevaluation. In addition to Dederer and Scott, see Steve Kurutz, "How Do You Solve a Problem Like Manhattan?" The New York Times, March 1 2018, https:/ / nyti.ms/2FHasqw (accessed 2018-11-2). 29 Scott, "My Woody Allen Problem."

30 Gaut, Art, p. 74.

31 Gaut, Art, p. 77.

32 Scott, "My Woody Allen Problem," emphasis mine.

33 While the starting point for this essay are individual accounts of feelings of betrayal relative to personally formative artworks and their artist, the individual dilemma is not strictly separable from a collective discussion about artworks and artists who have a place in the "common artistic record," and therefore have a formative role in the broader culture - even if they will not have the same value for every individual. For this reason, individuals who may not have felt themselves to have been specifically or especially formed by a high personal regard for Woody Allen (for example) may still be invested (if not to the same degree) in assessing his works and the ways they choose to relate to them. 


\section{Error, Betrayal, and Reassessment}

Nehamas briefly addresses a kind of betrayal that follows on disillusionment with the beloved or admired object, drawing on Proust's character Swann from In Search of Lost Time:

You can't even be certain that you will eventually consider what you find through the pursuit of beauty to have been worth your while. Perhaps you will feel about it as Swann came to feel about Odette after all the years he devoted to her: "To think that I have wasted years of my life, that I wanted to die, that I felt my deepest love, for a woman who did not appeal to me, who was not even my type!"34

For Nehamas, such disappointment is the risk of love: one pursues the beloved not knowing where it will lead, and it may lead down paths one eventually judges shameful. The betrayal is significant not only because the object no longer appears beautiful or compelling as it had previously, but because when one has made oneself vulnerable to transformation by a beloved and admired object, has given it a place in one's life and identity, the implications are not only evaluative (a reconsidered appraisal of its aesthetic value) but personal.

Elaine Scarry offers a more detailed account of how one may feel betrayed by an object or person one judged beautiful (or, I would say more broadly, held in high aesthetic regard). She describes a feeling of betrayal that results from errors of over-attribution: the feeling one has when a person or object one had regarded as beautiful (or aesthetically compelling) no longer appears so. Errors of over-attribution have "the peculiarity that when the person or thing ceases to appear beautiful, it often incites the perceiver to repudiate, scorn, or even denounce the object as an invalid candidate or carrier of beauty." 35 The object may be "turned upon, as though it has enacted a betrayal." 36 In these passages, Scarry is describing the "temptation to scorn the innocent object for ceasing to be beautiful," 37 but the dynamics are applicable beyond judgments of beauty as such to aesthetic involvements more broadly, just as the dynamics Nehamas describes apply to compelling, beloved objects broadly, since he thinks attraction and love involve a judgment of beauty in some sense.

Scarry clearly deems the repudiation of the reconsidered object excessive, in the case of an otherwise "innocent" object - but what if the beloved, admired object was made by one deemed criminal or abusive? What is the nature of the betrayal and what kind of repudiation and denunciation is appropriate? Scarry's discussion of aesthetic regard, error, and betrayal provides some preliminary pathways for reflection, but in the context of the current debate, her distinction between errors of over- and under-attribution of beauty is too limited a model. Dederer's question "what do we do with the art of monstrous men?" articulates a dilemma about how an artist's ethical conduct bears on one's aesthetic regard for and consumption of their works, but the sense of betrayal arises specifically when one is aesthetically involved with the work. ${ }^{38}$

\footnotetext{
34 Nehamas, Promise, p. 130.

35 Scarry, On Beauty and Being Just (Princeton: Princeton University Press, 2001), p. 49.

36 Scarry, On Beauty, p. 51.

37 Scarry, On Beauty, p. 49.

38 I note that the ethical dimensions of attributing aesthetic value are various and complex; a comprehensive treatment of this topic far exceeds the scope of this paper.
} 
One response, as Scarry details, is to revise one's regard for a work or an artist as an error of over-attribution: one considered an artist's work compelling, beautiful, or important, but in fact it is not. Insofar as an artist's ethical merits (or defects) may be expressed in the work in aesthetically relevant ways, such reconsiderations may indeed be pertinent (as in Gaut's claim above that biographical details may allow for a more focused and clear assessment of the works). ${ }^{39}$ But Dederer's and Scott's reflections show that revisiting the quality of one's aesthetic involvement is more complicated than mere revisions of aesthetic judgment. As Scott notes, he cannot "unwatch" Allen's movies. Though he recognizes that not watching Allen's movies is a legitimate response, he suggests that rather than attempting the impossible task of expunging Allen's impact on him, he may need to start all over again. I take him to mean that given Allen's imprint on him, and his sense of the possibly ugly and de-formative effects on him, a better response may be to re-watch his films with a new critical perspective. Such reassessment involves more reflexivity than Scarry describes in her description of responding to errors of overattribution.

Attributive errors may be more variable than simple errors of over- or underattribution. We might better name them errors of misattribution. Revising such errors may imply a steadfast attribution of aesthetic value in some respects while drastically revising that attribution in others. For example, one might still regard Allen's Manhattan as a cinematic landmark and admire its opening montage (as Dederer describes ${ }^{40}$ ), while unfavorably reassessing its uncritical portrait of the romantic relationship between a 42year-old Isaac (played by Allen) and a 17-year-old Tracy (Mariel Hemingway), as well as the unflattering gap between straightforward, sex-loving Tracy and the "brittle" anxious full-grown women in the movie. ${ }^{41}$ Or, to take a different and more egregious example, one might still on some level positively acknowledge the raw intensity of Marlon Brando's and Marie Schneider's performances in Bertolucci's Last Tango in Paris while reviling the deception that underlies the anal rape scene, which according to Schneider had not been included in the original script, and according to Bertolucci had been in the script but without the detail that butter would be used as a lubricant. Bertolucci admits that he and Brando deliberately concealed the detail about using butter from Schneider prior to filming the scene expressly for the purpose of eliciting a spontaneous response from her on film. ${ }^{42}$ Once informed by its staging, we see in the scene a continuity between the fictional violation depicted and the actual violation of the actress's autonomy by withholding information about the acts, involving her body, that would be depicted in the scene - and, further, a continuity between a deeply problematic attitude towards the woman depicted in the film (manifest in the rape) and a deeply problematic attitude toward the actress playing her part (manifest in the deliberate withholding of critical information regarding the depiction of acts to which her body would be subject).

39 As Gaut's model for "ethicism" suggests, the claim that certain ethical virtues or insights are aesthetically relevant does not entail the claim that all ethical virtues are aesthetically relevant nor that ethical considerations are exclusively or overridingly important for the aesthetic assessment of the work. See in particular Gaut, Art, pp. 57-66.

40 Dederer, "Monstrous Men."

41 Dederer, "Monstrous Men."

42 Elahe Izadi, "Why the 'Last Tango in Paris' rape scene is generating such an outcry now," The Washington Post, December 5 2016, https:/ / wapo.st/2g0vcLt?tid=ss_mail\&utm_term=.1b18e8f8fcec (accessed 2018-11-2). 
But such reassessments of works in light of relevant biographical details regarding the real-life artist do not only regard the works as such (as Gaut describes), they may also be deeply personal. The sense of betrayal reflects not simply an incomplete or misconstrued interpretation of a person or object's value but its intimately formative effects on a person in terms of aesthetic involvement, and, finally, the impact of this valuation and one's involvement with a work on those who may have suffered disregard at the artist's hands. Scott does not enter into extended detail of how he assesses Allen's impact on him, but he notes that he found Allen's status as a bookish sex symbol aspirational ("a masculine ideal"). Evidently, Allen shaped his sense of male and female desire, desirability, and of romantic relational dynamics. More broadly, the Woody Allen figure exhibits a sense of sexual entitlement while at the same time portraying the female rejects and replacements in ways that suit the character's wants - to reject, to replace. Dederer, for her part, connects Allen's lack of "moral shading" on "middle-aged men fucking teenage girls" to a "moral disregard for anything but the self" encapsulated in his infamous response to a question about Soon-Yi Previn - "the heart wants what it wants." 43

The point I want to emphasize here is not about whether Scott's reassessment of Allen following the renewed attention to the allegations of molesting Dylan Farrow is definitive in some generalizable way. Critical evaluations are always subject to contestation and revision. The point I want to emphasize is that Scott expresses his reassessment of Allen's works, and the sense of betrayal it entails, as also self-indicting. Scott thus makes the move Dederer sees as critically and uncharacteristically absent in Allen's work on this point: "Woody Allen's usual genius is one of self-indictment, and here is his one film where that self-indictment falters..." But Dederer's point is broader; she questions the self-serving nature of the failure in critical reception: "... and also he fucks a teenager, and that's the film that gets called a masterpiece? What exactly are these guys defending? Is it the film? Or something else?"44 Allen's failure of self-indictment mirrors the viewer's defense of Allen's artistry (which, Dederer implies, is itself a failure of self-indictment or at least self-examination). Scott, too, implies concern over the de-formative effects of Allen's place in the "common artistic record" inscribed by the critical adulation Allen received while critics ignored or minimized the "uglier aspects" of the films' portrayal of women and male-female relationships. Scott makes a move from reflection on his individual formation to the collective implications of minimizing - or even adulating certain works' de-formative elements.

A similar concern has been expressed regarding Louis C.K.'s comedy works - that what was often received as self-parodying may in fact have been self-serving. ${ }^{45}$ C.K. has admitted to the repeated sexual harassment of female colleagues by (non-consensually)

\footnotetext{
43 Dederer, "Monstrous Men."

44 Dederer, "Monstrous Men."

45 "The stories told by the women raise sharp questions about the anecdotes that Louis C.K. tells in his own comedy. He rose to fame in part by appearing to be candid about his flaws and sexual hang-ups, discussing and miming masturbation extensively in his act - an exaggerated riff that some of the women feel may have served as a cover for real misconduct." Melena Ryzik, Cara Buckley, and Jodi Kantor, "Louis C.K. Is Accused by 5 Women of Sexual Misconduct," The New York Times, November 9, 2017, https:/ / nyti.ms/2ho0aE0 (accessed 2018-11-6). See also Joe Berkowitz, "In A Post-Weinstein World, Louis CK's Movie Is a Total Disaster," Fast Company, October 20 2017, https:/ / www.fastcompany.com/40483261/in-a-post-weinstein-world-louis-cksmovie-is-a-total-disaster (accessed 2018-11-6).
} 
masturbating in their presence. His comedy work includes extended discussion and miming of masturbation and his 2017 film, I Love You, Daddy, includes a male character who pretends to masturbate in front of a female character. C.K.'s character is also depicted dismissing sexual abuse allegations against an Allen-esque character. Precisely in translating personal wrongdoing into comedic content, does C.K. minimize attitudes and acts that are both sexually and professionally degrading? Comedy, of course, can undermine the objects, acts, or attitudes it depicts by satirizing their flaws. This can be a powerful form of critique. But it can also normalize its objects through levity and trivialization. ${ }^{46}$ Certainly once one knows about Louis C.K.'s harassment, it is difficult to disassociate his masturbation bits from his actions towards his female colleagues and the impact on them. Reassessing his work, and one's own aesthetic involvement with it, in light of his admissions of sexual harassment may elicit feelings of shame and betrayal.

Reevaluating the art of those who are discovered to have committed morally reprehensible actions is particularly difficult when one has been shaped by that work, because it implies an evaluation not only of one's aesthetic regard for it but of the ways in which one has been shaped by it (one's aesthetic involvement with the work and/or artist). The sense of betrayal is visceral because the object's promise does not merely cease: if that object has taken its place in one's life, its perceived promise has shaped that life in ways one did not expect and is unhappy to discover. This bears on one's possible implication in the "uglier aspects" of such works. The betrayal regards the unforeseen or undiagnosed formative implications of aesthetic involvement. This betrayal requires a reconsideration not only of the object itself but of its place in one's life and its impact on one's self.

\section{The Problem with Monsters}

Dederer's evocation of "monstrous men" is problematic for the reflexive dimension of reassessment on a few levels. First, because not only men commit acts of sexual harassment and assault (though the disparately gendered nature of sexual harassment and assault should not be occluded). Second, because calling them these men "monstrous" risks simply setting them apart - cloistering them as exceptionally vicious. As Kate Manne notes in her recent book on the logic of misogyny, demonizing rapists obscures the prevalence of sexual assault. Monsters "are unintelligible, uncanny, and they are outwardly frightening." But rapists "are human, all too human, and they are very much among us. The idea of rapists as monsters exonerates by caricature." 47 As Manne argues, acknowledging and working to address the pervasiveness of sexual harassment and assault requires acknowledging the "banality of misogyny." 48 But to take the point further, rendering sexually deformed patterns of interaction monstrous in the exceptional sense evades a reflexive examination of one's own implication in misogyny more broadly. Framing the question in terms of

\footnotetext{
46 "It is often through humor (say through irony or satire) that people can keep making sexist and racist utterances." Sarah Ahmed, Living a Feminist Life (Durham: Duke University Press, 2017), p. 261.

47 Kate Manne, Down Girl: The Logic of Misogyny (Oxford: Oxford University Press, 2018), p. 198.

48 Manne, Down Girl, p. 211.
} 
"monstrous men" risks precluding the reflexive and collective reassessment that Scott, for example, describes. And Dederer is clearly attuned to this danger:

Something in us - in me-chimes to that awfulness, recognizes it in myself, is horrified by that recognition, and then thrills to the drama of loudly denouncing the monster in question. The psychic theater of the public condemnation of monsters can be seen as a kind of elaborate misdirection: nothing to see here. I'm no monster. Meanwhile, hey, you might want to take a closer look at that guy over there. ${ }^{49}$

But Dederer's response to this problem opens onto a third problem: that she then conflates monstrosity with the artistic impulse as such. She identifies monstrosity in the act and conditions of writing itself. There's a selfishness that creativity requires, she notes - there are clear echoes here of her accusation of Allen's "monstrous disregard" for others. Dederer worries that she's not quite monstrous enough for great art - but she knows she's monster enough to finish. ${ }^{50}$ The heart wants what it wants and the artist does what it takes to finish their work. But with this move, Dederer asserts the wrong kind of banality. This banality erases the very moral shading whose absence she noted in Allen, though from a different vantage. Dederer identifies the statutory rape of an adolescent girl in Manhattan as monstrous in the attitude of normalizing nonchalance towards that act; in her own shift to reflexivity, the everyday judgments a working artist parent/spouse makes about the use of their time become monstrous. In the first instance, the monstrous becomes banal in a way that effaces its monstrosity. In the second instance, the banal becomes monstrous with similar consequences - but only because Dederer targets the wrong object for critique. Had she focused (as she does elsewhere) on the ways in which Allen's latent misogyny is not just a feature of his particular moral failings but represents and reinforces our moral failings both as viewers or appreciators of his work but also as a collective in which he has occupied a place of cultural authority that rests on aesthetic regard for and involvement with his work, the connection between monstrous banality and banal monstrosity would have been clearer. Allen may be exceptional in certain regards, but in other regards he is not and neither are the male-female relations he portrays. This is the point that needs making, and that Dederer misses by shifting monstrosity to artistic ambition. I am sympathetic to the reflexivity Dederer displays but worry that the monster language either cloisters the "bad guys" as exceptional cases or makes monsters of us all in ways that ultimately preclude meaningful critical assessment in both cases.

Naming the process Dederer and Scott are engaged in as discerning the contours of possible ethical deformation in their practices of aesthetic involvement is a better alternative. Deformation admits of a spectrum of gravity and specificity without losing the importance of banality in the sense that we are all imperfectly formed, subject to distortions great and small. If aesthetic involvement is or may be in certain respects ethically formative, then the problem Dederer and Scott are describing has to do with ethicallydeformed artists/artworks and the aesthetic involvement viewers develop with them. If aesthetic involvement is formative, deformation refers to the ways in which aesthetic formation may be for the worse: how it may misshape a person's affections, sensibilities, dispositions, their sense of what is attractive and repulsive, their sense of what is right or

49 Dederer, "Monstrous Men."

50 "Finishers are always monsters." Dederer, "Monstrous Men." 
good or at the very least, permissible, excusable. Deformation cannot only be identified in the artist and/or their works, but in the perceiver who (and collectively, the culture that) bestows regard upon them. Though Scarry and Nehamas address the possibility of error, betrayal, and deformation (being "shaped for the worse" as Nehamas says) to some extent, neither really addresses the problem of one's possible implication in ethically problematic social and cultural structures of aesthetic involvement. They do not address how to respond to aesthetic betrayals both personal and social beyond simply repudiating the object, which risks eliding the reflexive examination of how the betrayal may reveal one's implication in possibly distorting forms and structures of aesthetic involvement. The formative sources that shape aesthetic involvement can be implicated in distortions in one's view of the world or of relationships with others: our aesthetic involvement may thus render one complicit in perpetuating such views or in the consequences they have in relationships with others. Returning to the Louis C.K. example, continuing to treat his jokes with levity risks trivializing his (and similar) actions, with real consequences for women who have such experiences. Of course, one risks being labelled a killjoy for refusing to laugh at such jokes - but that, in fact, is precisely the point, and one of comedy's potentially uglier aspects. ${ }^{51}$

\section{An Interrogative Feminist Ethics of Aesthetic Involvement}

Once one knows about an artist's reprehensible actions or ideologies, how one evaluates the ethical stakes of engaging that art/ist requires looking both at how an artist's vices may infect (or not) the work, their relationships within the artistic community, and those who spend time, attention, acclaim, and money within that web of relationships. One can understand the deformation that creates a sense of betrayal only by looking at how viewers assess the aesthetic involvement they may have had with artists and/or their works and its formative implications.

To be clear, I take it that when it comes to the wrongdoing the artist commits directly against specific persons (people harassed, molested, assaulted, or otherwise degraded, manipulated, or harmed), the artist is fully responsible and culpable for his or her actions toward these people and is accountable to the legal and moral mechanisms that pertain. Of course, a strong collective aesthetic involvement with an artist and/or their works creates a position of power that can undermine precisely the enforcement of these mechanisms for accountability - this is no small difficulty, and points to the ways in which individual and collective responsibility are connected. But nevertheless, understanding a culpable artist's relationship to their art and to the viewer of that art is more ambiguous. The question "what do we do with the accused artist's art" requires us to ask how we evaluate art and our ethical responsibility in consuming it in light of an artist's actions, how we evaluate the art/ist's formative effects on its viewers/us, and how we evaluate the possible effects of our engagement and appreciation on others. Understanding the ethical stakes requires all three of these dimensions. I note that thus far, I have not suggested what accusations against an artist imply for the viewer's actions; I have not suggested that one should necessarily stop watching Louis C.K. or Manhattan or Last Tango in Paris. Indeed, part of my aim in this paper is precisely to refuse a linear, self-evident, or categorical path

51 Ahmed, Feminist Life, pp. 261-2. 
from sexual harassment or abuse (allegations or convictions) to either boycotting all works associated with allegations or disassociating the art from the artists on principle. Rather, I want to suggest that discerning responses to the many and various cases that may be implicated by allegations of moral reprehensibility (sexual and otherwise) will not be resolved by appeal to a single normative principle, or as Gaut puts it, "a general theoretical edict." 52 Responses can only be discerned by considering a range of questions about both the work at hand and the relationships involved. I note that the relevant questions here concern both aesthetic assessment of the work and one's aesthetic involvement with it as well broader questions about consumption of that work as such:

1) Regarding an artist's actions: What is the nature of the artist's actions? Have the artist's actions or has the artist's character deformed the work? How? How have they damaged or undermined the artistic community of which they are a part?

2) Regarding the art/ist's relationship to or effects on viewers: What mark has the artist's work left on me or on others close to me? How does knowing about the artist's actions affect my assessment of the work and/or my willingness to engage the work? What mark has this art/ist left on the "common artistic record"? How does that mark inform memory and experience? What does it lift up, what does it critique, what does it leave unsaid or undisturbed?

3) Regarding the effects of engagement or consumption on those who have been harmed: How might my engagement affect those who have suffered or might suffer from the artist's actions? How might my engagement continue to support (or not) an artist's position of power and influence in ways that might reinforce impunity?

4) Regarding questions to address if/when one engages the art/ist: Whose voices do I need to listen to before or as I continue to engage this work? How should I, if I do, work with this artist's work? How should the artists' actions influence the substance and focus of my engagement?

The argument for or against continuing to engage and how to engage an artist's work (if one so chooses) develops through such a process: an interrogative approach to the feminist ethics of aesthetic involvement and consumption. Any one person's judgment on these matters may subsequently be subject to contestation by others or to reassessment on one's own terms. Such a process will yield varying arguments; the arguments will be as variable as the responses to the questions themselves, for an art/ist's impact on one viewer or another will not be straightforward, predictable, or uniform. Responses to and interpretations of specific works of art and the artists who make them vary widely, and where one sees an offense, another sees a critique of precisely what the other takes as offensive. This range of interpretation is essential. Answerability for one's position and contestability of that position work together. For this reason, I take the process of discernment I am sketching as first of all a personal and contextual one, one that individuals undertake, that allow them then to make judgments that can be articulated to others. Dederer, too, is critical of the "we" - she rejects the false, imposing authority it implies. The real question, she suggests, is "can I love the art but hate the artist?"53 Part of

52 Gaut, Art, p. 74.

53 Dederer, "Monstrous Men." But the "we" in Dederer's title is nevertheless telling, because these debates have issued in questions about whether the response to an artist's wrongdoing should 
my argument for the approach I am proposing rests on the claim that in most cases, "we" should not restrict or condemn ongoing engagement with an artist's work as such (though we certainly might criticize ongoing engagement that fails to account for the kinds of considerations I have just outlined). Here, I focus on judgments that one must make in contexts where few works are inaccessible as such and debate about the ethics of viewership, consumption, and aesthetic involvement is active.

Before proceeding, let me note that there are a number of arguments to be made for not engaging an artist's work without fully responding to the set of questions I have detailed: one is not invested in the works at issue ${ }^{54}$; one finds the prospect of engaging traumatic or triggering; one prefers to bestow one's attention on other artists, particularly artists who may have been sidelined or who have suffered as a result of this artist's actions. I take it that there is a moral responsibility of "lateral regard" that stands regardless of the decision to engage a reprehensible artist's work. Lateral regard is a term I'm borrowing from Scarry but applying differently in light of concerns about male and racial domination in particular fields. Lateral regard entails expanding the range of one's aesthetic attention - the feminist twist is to specify that there is a particular obligation to expand this regard to the often underappreciated work of women and minorities. This responsibility inheres in a feminist ethics of aesthetic involvement whether or not one chooses to continue to engage with work by dominant (and dominantly male) artists accused of sexual harassment or abuse, though such responsibility is heightened if one chooses to do so. There are two reasons for this. First, lateral regard acts as a counterweight to the ways in which continuing to engage the works of certain artists - even critically - continues to enforce their importance in a kind of cultural canon, or collective artistic record as Scott puts it. Second, lateral regard contributes to honing one's critical perspective, which requires serious and sustained attention to the voices of those most negatively affected by structures of domination. Lateral regard is fundamental to diversifying the voices and works that receive attention, acclaim, and engagement where imbalances persist.

require a more collective response about removing an artist's work from a public or private space: should "we" make decisions about the accessibility of an artist's work that will override to an extent an individual's judgments about engagement? Think of Netflix's removal of Louis C.K.'s work from their platform or post-WWII German prohibitions on screening Leni Riefenstahl's Triumph of the Will, the cinematographically acclaimed and equally reviled documentary film chronicling the 1934 Nazi party congress. How are such collective judgments reached and enforced? How might they be contested? Questions around collective judgments on prohibiting access to certain works exceed the scope of this paper; generally speaking, I take censorship to be a very weighty act requiring a heavy burden of argumentation.

54 The refusal to read David Foster Wallace, for example, crops up in more than one recent piece. See Amy Hungerford, “On Not Reading,” The Chronicle of Higher Education, September 11 2016, https:/ / www.chronicle.com/article/On-Refusing-to-Read/237717 (accessed 2018-11-6); Deirdre Coyle, "Men Recommend David Foster Wallace to Me," Electric Lit, April 17, 2017, https:/ / electricliterature.com/men-recommend-david-foster-wallace-to-me-7889a9dc6f03 (accessed 2018-11-6). While I fall into the non-reading group on this particular author, I admire and respect Clare Hayes-Brady's articulation of how she approaches reading Foster Wallace in light of his domestic abuse and overt misogyny. See "David Foster Wallace in the \#MeToo Era: A Conversation with Clare Hayes-Brady," Los Angeles Review of Books, September 10, 2018, https:/ / lareviewofbooks.org/article/david-foster-wallace-in-the-metoo-era-a-conversation-withclare-hayes-brady/ (accessed 2018-11-8). 
Returning to the prior point: there are good reasons simply not to engage an artist's work without going to extensive justificatory lengths. Critical and diagnostic work is essential; but it is not the only work to be done, and not everyone needs to take it on. But there are a number of reasons or cases in which one will need to weigh the questions and concerns I have detailed: when one has a relationship to the art/ist in question, whether at a deep personal level, a professional level, or because one cares about the social and cultural concerns at issue; where one feels that certain (potentially) de-formative dimensions of the work require diagnosis, whether personally or collectively. The impetus for A.O. Scott to invest time in revisiting the films that shaped him with a critical perspective is distinct from a casual viewer or the uninitiated. One will have to weigh these considerations in light of the question of lateral regard (attending to the work of other artists) and economic/cultural support (particularly in the case of living artists). If one chooses to engage, one has a responsibility to consider how one's engagement might impact others negatively, and to consider how one might precisely through one's engagement address the de-formative qualities of the art/ist. At a minimum, one's engagement should account for and acknowledge possible tensions and difficulties in the work; the recently reconsidered approach to an exhibition on Casanova (previously titled "The Seduction of Europe") is an example of how \#MeToo prompted a more critical appraisal of how to present certain works. ${ }^{55}$ To go a step further, one might ask whether one's engagement might precisely seek to form readers, listeners, viewers in ways that create better kinds of attentiveness, that move towards some form of redress?

For illustrative purposes, I will run through how I might apply the questions to a couple of examples. I note that these reflect my own contestable responses. Let's begin with Allen, since he is a recurrent example in the accounts I have discussed. First, regarding the nature of his actions: I take the molestation allegations to be the most serious ones. Evaluating them in light of the investigation proceedings in 1992 and 1993 is not straightforward, as the proceedings are muddled by accusations on both sides: that Mia Farrow coached Dylan, seeking revenge for Allen's relationship with Soon-Yi; that the Yale-New Haven hospital report clearing Allen of abuse charges was seriously flawed. More recently, however, Dylan Farrow's own testimony made public in 2014 via the New York Times carries a great deal of weight. ${ }^{56}$ The ensuing conflicting public responses by various family members should not obscure Farrow's voice. The difficulty in many sexual harassment and assault cases is that testimonies are often all one has to judge. Without drawing a clear judgment on Allen's guilt or innocence per se, I find it impossible to disassociate the accusations against Allen from my response to his work.

Second, regarding the relationship to and effects on viewers: as Dederer and Scott both describe, I cannot dissociate the "manifest Woody," whose relationships to and views of girls and women are ethically problematic, from the real-life accusations against him. I

55 Kimberly Chrisman-Campbell, "When Casanova Met \#MeToo," The Boston Globe, March 3, 2018, https:/ / www.bostonglobe.com/ideas/2018/03/03/when-casanova-metmetoo/ALNHZdUQJJZ41KKylv8hqM/story.html (accessed 2018-11-6); Cynthia Durcanin, "Casanova as Case Study: How Should Art Museums Present Problematic Aspects of the Past ?," Art News, August 13, 2018, http:/ / www.artnews.com/2018/08/13/casanova-case-study-artmuseums-present-problematic-aspects-past/ (accessed 2018-11-6).

56 Dylan Farrow, "An Open Letter from Dylan Farrow," The New York Times, February 1, 2014, https:/ / kristof.blogs.nytimes.com/2014/02/01/an-open-letter-from-dylan-farrow/ (accessed 201811-7). 
note that this is a judgment about Allen specifically, and not a generalizable point discontinuities are certainly possible between the manifest artist and the real-life artist, between work and biography. Part of what gives rise to the aesthetic questions regarding Allen's work (and not just questions about the ethics of consumption) is that the question of continuity is salient. Further, Allen has been both critically acclaimed and successful with popular audiences, which has made him an influential cultural icon. That is, as an artist he has been highly regarded by many individuals and has received a significant level of cultural regard. As such, his characterizations of male-female relationships and attitudes toward women are well-positioned to influence perception: Dederer and Scott both describe the impact on themselves and beyond, in their social circles and the conversations they have with others. They both describe the impulse to ignore the "uglier aspects" of these and/or to defend and glamourize Allen as a "masculine ideal" and (at least some of) his films as aesthetic and cinematic masterpieces. This entails not only a critical failure to engage the work's uglier aspects but, further, contributes to normalizing those very aspects of male-female interactions and attitudes toward women.

Third, regarding the effects of consuming Allen's works on those who have been harmed, Dylan Farrow's closing appeal in her open letter carries quite a bit of force on this front: "So imagine your seven-year-old daughter being led into an attic by Woody Allen. Imagine she spends a lifetime stricken with nausea at the mention of his name. Imagine a world that celebrates her tormenter. Are you imagining that? Now, what's your favorite Woody Allen movie?" ${ }^{77}$ Continuing to engage Allen uncritically reinforces Allen's position of cultural influence in ways that Farrow testifies as profoundly hurtful. In light of the consideration on the second set of questions, uncritical reinforcement of his status as a cultural and cinematic icon (a form of aesthetic involvement) also risks continuing to ignore the problematic aspects of his portrayals of women and relationships - and, more broadly, similar portrayals or attitudes more broadly beyond Allen's œuvre alone (for if we defend Allen on this front, we will probably also fail to examine similar attitudes and portrayals in other art whether or not the artists in question are in any way personally culpable for reprehensible acts). Beyond questions about engagement on a cultural level there is the issue of economic support entailed by consumption, which is difficult to extract from the question of reinforcing aesthetic involvement in terms of his cultural status. On this point, the third and fourth sets of questions dovetail. I take any engagement of Allen as an artist and his works to imply a critical burden. That is to say, engagement of his films should take seriously the need to critically examine his portrayals of girls and women, male-female patterns of interaction, and male-female desires and desirability. This kind of assessment of his works is both ethically and aesthetically relevant. But this by no means implies that we should collectively refocus our attention on Allen and his works specifically (or that any attention to Allen's works must focus on these dimensions alone). On the one hand, awareness of the problematic dimensions of Allen's work should prompt attention to these same dimensions in other social-cultural artistic representations - not a narrow fixation on Allen alone. On the other hand, and more constructively, it is important to broaden attention to other artists, to practice the virtue of lateral regard. I won't say that I will never watch another Woody Allen film, but if and when I do, I will be attentive to the conditions of my viewing, the critical perspective I bring to it, and its relative place in my cinematic diet more broadly.

57 Farrow, “Open Letter." 
Briefly, I will address a few points of deviation from the Allen or C.K. cases, in which the artists' personal lives and the contents of their works are closely aligned. First of all, we might consider an artist accused of sexual harassment or abuse whose actions are not, or are not self-evidently, reflected in the art itself. Bill Cosby, for example, perturbs less because of a continuity between his personal life and his character than because of its discontinuity: the rapist who plays the loveable family man. Not all of the same questions around consuming The Cosby Show apply as they do to Manhattan (this reflects, in part, the difference between acting and directing). Nevertheless, the same questions about the extent to which Cosby's sexual assault record influences the consumption of his work (particularly insofar as it might entail economic support and cultural status) and the discussion of his significance as a cultural icon do apply. Second, historical context matters in evaluating an artist's actions even if it does not simply excuse actions deemed reprehensible by contemporary standards. For example, Paul Gauguin is one of the modern art figures who has attracted some of the most excoriating post-colonialist and feminist critique - and rightly so. ${ }^{58}$ Gauguin abandoned his wife and five children in search of an idealized, "primitive" Eden in the French-colonized Polynesian islands. There he took three teenage brides (between the ages of 13 and 14), whom, in addition to painting, he may or may not have infected with syphilis. ${ }^{59}$ That Gauguin's behavior would not have been perceived the same way by the standards of the time as it is by ours does not diminish the force of the contemporary moral evaluation one makes of his participation in colonial and sexual practices abhorrent on contemporary terms and the question of how to view, interpret, and respond to his works in light of that evaluation. It is, nevertheless, important to situate Gauguin in his context just as one's own judgment is situated in a particular context: both historical and contemporary context should inform how one understands and evaluates both his actions, his works, and influence (in all of its possible range, positive and negative). ${ }^{60}$ This does not imply homogenous interpretations or valuations of his works - feminist interpretations of the works and their relationship to his life and his influence may vary widely, and are by no means bound to reach specific conclusions. Assessment of his work may attend both to the aesthetically relevant ethical dimensions of the works (for example, the attitudes implied towards its subjects; the character of both the "manifest artist" and the real-life artist) and to its other aesthetic qualities.

Part of the question that Gauguin's work opens up is the role of institutions such as museums and galleries in integrating critique. On this point, I argue that exhibitions and discussions of Gauguin's works should present post-colonialist and feminist accounts of imperial tourism and colonial exoticism just as they present accounts of his place in

58 Paul van der Grijp, Art and Exoticism: An Anthropology of the Yearning for Authenticity (Berlin: LIT Verlag, 2009); Griselda Pollock, Avant-Garde Gambits 1888-1893: Gender and the Color of Art History (London: Thames \& Hudson, 1993); Abigail Solomon-Godeau, “Going Native: Paul Gauguin and the Invention of Primitivist Modernism," in Art in America 77 (July 1989), pp. 118-29; Belinda Thomson (ed), Gauguin: Maker of Myth (London: Tate Modern, 2010).

59 This dominant assertion has recently been qualified, as a set of teeth that are very likely Gauguin's have shown no evidence of mercury, the treatment for syphilis at the time, therefore implying either that he did not have syphilis or simply that he was not treated for it. William A Mueller and Caroline Boyle Turner, “Gauguin's Teeth," Anthropology 6 :1 (2018), DOI :

10.4172/2332-0915.1000198.

60 See Gaut, Art, pp. 79-80, on historical context. 
developments in modern art. ${ }^{61}$ Moreover, art institutions also have a responsibility to practice lateral regard. The Guggenheim's exhibition of Hilma af Klint's work, long underrecognized for its innovative abstraction that preceded Kandinsky, Malevich, and Mondrian (typically credited as the innovators of non-representative art), is an example of how attending to underrepresented figures may invite a reevaluation of a received artistic canon and history. ${ }^{6}$

The institutional dimension raises questions about how to assess individual actions that reflect and contribute to collective socio-cultural structures. This touches questions about how art - regardless of an artist's personal life - reflects and participates in social and cultural structures informed by norms and values that may be distorted. This is an issue that I will not fully address, as I focus on artists who have been accused of morally and/or criminally reprehensible actions. But insofar as individual and collective moral-aesthetic formation and responsibility are intertwined, as I think they are, the boundaries of these discussions are porous. The formative dimension of aesthetic involvement and consumption raises questions about answerability and responsibility. This requires recognizing how both artists and viewers are formed in variously distorted social structures and that both artists and viewers ought to consider and respond to their implication - both attitudinal and active - in these distorted structures.

The meaning of individual acts is found in the nexus of practices, dispositions, and affections in which they are taken. ${ }^{63}$ This means that human action is inextricable from the (distorted) social structures in which it is situated. One may thus be pervasively implicated in collectively distorted structures. This raises questions about the extent to which we are answerable and responsible for our participation in those structures, especially insofar as we may have been non-deliberately formed by them. ${ }^{64}$ Regardless of how one frames the principle of answerability and responsibility on an ethical theoretical front, one ought to take seriously and respond to contestations of one's implicit assumptions and attitudes and the actions to which they lead, when such contestations arise. Insofar as aesthetic involvement may dovetail with moral formation, such contestations of one's implicit assumptions and attitudes may emerge in response to aesthetic betrayals of the sort I have discussed in this paper. Though I do not engage the question of collective judgments on prohibit access to certain works, I have touched on the heightened obligation that institutions and their members bear for considering how they present artists and their artworks, and the kinds of involvements they have with the works and foster in the public, insofar as they have a role in framing and direction attention to artists and works. I am not suggesting any particular default position by art institutions or art historians. But the

61 This is a judgment regarding art institutions and critics who are engaging Gauguin given his place in a "common artistic record." This reflects the reality that one's position in a field relative to certain artists also influences one's consideration of whether or not to engage an artist.

62 Caitlin Dover, "Who Was Hilma af Klint?: At the Guggenheim, Paintings by an Artist Ahead of Her Time," October 11, 2018, https:/ / www.guggenheim.org/blogs/checklist/who-was-hilma-afklint-at-the-guggenheim-paintings-by-an-artist-ahead-of-her-time (accessed 2018-11-8).

63 Ryan Darr, "Social Sin and Social Wrongs: Moral Responsibility in a Structurally Disordered World," Journal of the Society of Christian Ethics 37:2 (Fall/Winter 2017), pp. 21-37.

64 For one such account, see Ryan Darr's claim that "intersubjective answerability" means that "then we are responsible not only for that which is freely chosen or under voluntary control but also for anything for which it is possible to give reasons and which is, at least in principle, open to modification by rational considerations." Darr, "Social Wrongs," p. 29. 
question of how we should respond to art by artists who have been accused of sexual wrongdoing arises when the art and the artist are already embedded in formative relationships of some kind: that is, in existing structures of aesthetic involvement. Reflexive consideration of one's responsibility falls more heavily on those who are involved with the artworks or artist in some regard, and institutions and persons involved in existing structures by virtue of their profession, expertise, or field of study are inevitably in such positions of heightened consideration.

Throughout this article, I have focused on the question of what we should do with the art of the accused. In doing so, I do not want to confuse the responsibility harassers and abusers bear for their actions and the responsibility viewers bear in evaluating their implication. But my purpose has been to articulate how to respond to wrongdoing as a viewer, and I have argued that this requires reflexive and social-structural examination. A reflexive move is necessary in cases where one discovers oneself to be implicated as a viewer, as an appreciator, as someone who becomes aesthetically involved with people and things and works and is shaped by them. Reassessing a work requires consideration not only of the object's aesthetic value but of the formative implications of aesthetic involvement, individually and collectively. It also means that ongoing engagement with artist's work can and should be recognized as a legitimate dimension of grappling with deformation and its harms, and that this can be compatible with appreciation of and interpretive attention to the works. At the same time, I have tried to articulate conditions and considerations for engagement that address the responsibility one has for considering how and why one chooses to engage, in ways that will presumably inflect that engagement in important ways.

Sarah Stewart-Kroeker, University of Geneva sarah.stewart-kroeker@unige.ch

\section{Bibliography}

Ahmed, Sarah. Living a Feminist Life. Durham: Duke University Press, 2017.

Berkowitz, Joe. "In A Post-Weinstein World, Louis CK's Movie Is a Total Disaster." Fast Company, October 20 2017. https://www.fastcompany.com/40483261/in-a-postweinstein-world-louis-cks-movie-is-a-total-disaster. Accessed 2018-11-6.

Chrisman-Campbell, Kimberly. "When Casanova Met \#MeToo." The Boston Globe, March 3, 2018. https://www.bostonglobe.com/ideas/2018/03/03/when-casanova-metmetoo/ALNHZdUQJJZ41KKylv8hqM/story.html. Acessed 2018-11-6.

Coyle, Deirdre. “Men Recommend David Foster Wallace to Me.” Electric Lit, April 17, 2017. https:// electricliterature.com/men-recommend-david-foster-wallace-to-me7889a9dc6f03. Accessed 2018-11-6.

Cramer, David, Jenny Howell, Jonathan Tran, Paul Martens, "Scandalizing John Howard Yoder," The Other Journal: An Intersection of Theology \& Culture, July 7, 2014. https://theotherjournal.com/2014/07/07/scandalizing-john-howard-yoder/. Accessed 2018-11-8.

Darr, Ryan. "Social Sin and Social Wrongs: Moral Responsibility in a Structurally Disordered World." Journal of the Society of Christian Ethics 37:2 (Fall/Winter 2017), pp. 21-37. 
Deb, Sopan and Deborah Leiderman. "Woody Allen, Mia Farrow, Soon-Yi Previn, Dylan Farrow: A Timeline." The New York Times, January 31, 2018. https://www.nytimes.com/2018/01/31/movies/woody-allen-mia-farrow-dylanfarrow-a-timeline.html. Accessed 2018-11-2.

Dederer, Claire. "What Do We Do With the Art of Monstrous Men?" The Paris Review, November 20, 2017. https://www.theparisreview.org/blog/2017/11/20/artmonstrous-men/. Accessed 2018-11-8.

Donegan, Moira. "I Started the Media Men List. My name is Moira Donegan." The Cut, January 10, 2018. https://www.thecut.com/2018/01/moira-donegan-i-started-themedia-men-list.html. Accessed 2018-11-8.

Dover, Caitlin. "Who Was Hilma af Klint?: At the Guggenheim, Paintings by an Artist Ahead of Her Time." October 11, 2018, https://www.guggenheim.org/blogs/checklist/who-was-hilma-af-klint-at-theguggenheim-paintings-by-an-artist-ahead-of-her-time. Accessed 2018-11-8.

Durcanin, Cynthia. "Casanova as Case Study: How Should Art Museums Present Problematic Aspects of the Past?" Art News, August 13, 2018. http://www.artnews.com/2018/08/13/casanova-case-study-art-museums-presentproblematic-aspects-past/. Accessed 2018-11-6.

Farin, Ingo and Jeff Malpas (eds). Reading Heidegger's Black Notebooks 1931-1941. Cambridge: MIT Press, 2016.

Farrow, Dylan. "An Open Letter from Dylan Farrow." The New York Times, February 1, 2014. https://kristof.blogs.nytimes.com/2014/02/01/an-open-letter-from-dylanfarrow/. Accessed 2018-11-7.

Gaut, Berys. Art, Emotion and Ethics. Oxford: Oxford University Press, 2007.

Goossen, Rachel Waltner. "Defanging the Beast: Mennonite Responses to John Howard Yoder's Sexual Abuse." Mennonite Quarterly Review 89 (January 2015), pp. 7-80.

Hauerwas, Stanley. "In Defence of 'Our Respectable Culture': Trying to Make Sense of John Howard Yoder's Sexual Abuse." ABC Religion and Ethics, October 18, 2017. http://www.abc.net.au/religion/articles/2017/10/18/4751367.htm. Accessed 201811-8.

Hess, Amanda. "How the Myth of the Artistic Genius Excuses the Abuse of Women." The New York Times, November 2017. https://www.nytimes.com/2017/11/10/arts/sexual-harassment-arthollywood.html. Accessed 2018-11-8.

Hungerford, Amy. “On Not Reading." The Chronicle of Higher Education, September 112016. https://www.chronicle.com/article/On-Refusing-to-Read/237717. Accessed 2018-116.

Izadi, Elahe. "Why the 'Last Tango in Paris' rape scene is generating such an outcry now." The Washington Post, December 5016. https://wapo.st/2g0vcLt?tid=ss_mail\&utm_term=.1b18e8f8fcec. Accessed 2018-11-2.

Kolitz, Daniel. "Academics Explain David Foster Wallace To Me." The Outline, July 25, 2018, https://theoutline.com/post/5543/david-foster-wallace-conferenceprofile?zd=1\&zi=hoxjdain. Accessed 2018-11-8.

Kurutz, Steve. "How Do You Solve a Problem Like Manhattan?" The New York Times, March 1 2018. https:/ / nyti.ms/2FHasqw. Accessed 2018-11-2.

Lyall, Sarah and David Itzkoff. "Charlie Rose, Louis C.K., Kevin Spacey: Rebuked. Now What Do We Do With Their Work?" The New York Times, November 24, 2017. 
https:// www.nytimes.com/2017/11/24/arts/charlie-rose-kevin-spacey-louis-ckart.html. Accessed 2018-11-8.

Manne, Kate. Down Girl: The Logic of Misogyny. Oxford: Oxford University Press, 2018.

Mintcheva, Svetlana. "Caravaggio killed a man. Should we therefore censor his art?" The Guardian, February 3, 2018.

https://www.theguardian.com/commentisfree/2018/feb/03/caravaggio-killed-aman-censor-art?CMP=share_btn_fb. Accessed 2018-11-8.

Mitchell, Andrew and Peter Trawny (eds). Heidegger's Black Notebooks: Responses to AntiSemitism. Columbia University Press, 2017.

Mueller, William A. and Caroline Boyle Turner. “Gauguin's Teeth.” Anthropology 6:1 (2018). DOI : 10.4172/2332-0915.1000198.

Nehamas, Alexander. Only a Promise of Happiness: The Place of Beauty in a World of Art. Princeton: Princeton University Press, 2007.

Paulson, Steve and Claire Hayes-Brady. "David Foster Wallace in the \#MeToo Era: A Conversation with Clare Hayes-Brady." Los Angeles Review of Books, September 10, 2018. https:/ / lareviewofbooks.org/article/david-foster-wallace-in-the-metoo-era-aconversation-with-clare-hayes-brady/. Accessed 2018-11-8.

Pollock, Griselda. Avant-Garde Gambits 1888-1893: Gender and the Color of Art History. London: Thames \& Hudson, 1993.

Ryzik, Melena, Cara Buckley, and Jodi Kantor. "Louis C.K. Is Accused by 5 Women of Sexual Misconduct." The New York Times, November 9, 2017. https:/ / nyti.ms/2ho0aE0. Accessed 2018-11-6.

Rothfeld, Becca. "Can Sexual Predators Be Good Scholars?" The Chronicle of Higher Education, December 07 2017. https://www.chronicle.com/article/Can-SexualPredators-Be-Good/242002?cid=wcontentgrid_40_5. Accessed 2018-11-8.

Scarry, Elaine. On Beauty and Being Just. Princeton: Princeton University Press, 2001.

Scarsella, Hilary. “Not Making Sense: Why Stanley Hauerwas's Response to Yoder's Sexual Abuse Misses the Mark." ABC Religion and Ethics, Updated 1 Dec 2017 (First posted 30 Nov 2017). http://www.abc.net.au/religion/articles/2017/11/30/4774014.htm. Accessed 2018-11-8.

Scott, A.O. "My Woody Allen Problem." The New York Times, January 312018. https://www.nytimes.com/2018/01/31/movies/woody-allen.html. Accessed 201811-8.

Solomon-Godeau, Abigail. "Going Native: Paul Gauguin and the Invention of Primitivist Modernism." in Art in America 77 (July 1989), pp. 118-29.

Thomson, Belinda (ed). Gauguin: Maker of Myth. London: Tate Modern, 2010.

van der Grijp, Paul. Art and Exoticism: An Anthropology of the Yearning for Authenticity. Berlin: LIT Verlag, 2009. 
De Ethica. A Journal of Philosophical, Theological and Applied Ethics Vol. 6:1 (2020) 